\title{
DOI https://doi.org/10.30525/978-9934-26-120-6-30
}

\section{ФЕНОМЕН КРАСИ В СУЧАСНОМУ ПУБЛІЧНОМУ ПРОСТОРІ МІЖ ДУХОВНІСТЮ ТА ТІЛЕСНІСТЮ}

\author{
Васильсва Л. А. \\ кандидат філософських наук, доиент, \\ доиент кафедри філософії та суспільних наук \\ Національний аерокосмічний університет імені М. С. Жуковського \\ «Харківський авіаційний інститут» \\ м. Харків, Украӥна
}

Філософи $з$ давніх часів розмірковують над феноменом краси, в той час як сучасне суспільство усіма силами намагається на ньому заробляти, оскільки однією з характерних рис сучасної людини публічної $\epsilon$ інтенсивне культивування зовнішнього вигляду та впровадження канону перебільшеної краси в інформаційний простір. «Історія знову й знову переконує нас, що життєві практики культури можуть бути й деструктивними. Це відбувається як правило поступово - через життєвий світ творців та глядачів культури, в неї проникає моральна й екзистенціальна потворність. Наявність внутрішньої краси у світогляді, у вчинках та відносинах не дає культурі перейти червону межу, за якою вона стає антикультурою й псевдокультурою» [6, с. 53].

Наукова думка вже багато століть намагається розв'язати проблему вираження та розуміння поняття краси. Однак ці спроби завжди мали досить дискусійний характер. Століттями зовнішні канони краси змінювались, але тілесна врода завжди привертала увагу, полонила серце та розпалювала емоції людини. Коли говорять, що «краса в очах того, хто дивиться», акцент робиться зазвичай на зовнішній складовій, яка вже начебто включає внутрішне «Я» людини, тобто краса, яка апріорі розглядається як цілісність.

М. Лютер був першим західним мислителем, який сформулював ідею внутрішнього «Я» [9], розділивши поняття краси на зовнішню та внутрішню ії складову та доводив, що людина має двоїсту природу, поєднуючи в собі внутрішню духовну сутність й зовнішню тілесну значущість. Саме духовну красу людини він наділив більшою цінністю, відкинувши абсолютну затребуваність зовнішньої краси соціальної істоти. Чи не означає це, що сучасна людина, шукаючи лише зовнішню красу, забуває про духовні глибини свого «Я»? Адже відомо, що красива людина, яка 3 дитинства оточена надмірною увагою інших, 
може бути надзвичайно нарцисичною, поверхневою, неглибокою, що штовхає іiі до «штучного», удаваного життя на буденному рівні. Така людина не здатна помічати істину красу й нічого не цінує, окрім самої себе.

На нашу думку, детермінованість власною тілесністю не може бути абсолютною, оскільки в тій чи іншій мірі в людині існують прояви екзистенціального, морального, духовного, що здатне вийти за межі їі буденного нарцисизму. Інше питання чи готова така людина бачити такі прояви?

Англійська дослідниця Ненсі Еткофф, осмислюючи феномен зовнішньої краси, зазначає, що сучасна людина «живе в еру бридкої краси, коли врода стає моральною підозрою, а потворність заманливо приваблює» [10, с. 9]. Дослідниця вважає, що красу порівну становлять плоть i уява, яку людина наповнюе своїми мріями та насичує бажаннями. Інакше кажучи, благовоління перед красою - це лише втеча від самої реальності, «наш внутрішній підліток, який постійно відмовляється погодитись із недосконалістю світу» [10, с. 24].

В сучасному квазіпублічному просторі саме зовнішній вигляд стає найзатребуваним проявом сутності людини, найлегшим та найпростішим способом штучного віддзеркалювання внутрішнього світу, коли легко привласнюються гламурні образи та канони перебільшеної краси. При цьому залишається питання: Чому одні люди бажають грошей, безпеки та зовнішньої краси, тоді «як інші воліють померти заради мети або витратити час і гроші на допомогу іншим» [9, с. 26]? Таке розділене прагнення сучасний американський дослідник Френсіс Фукуяма в своїй роботі «Ідентичність: потреба в гідності й політика скривдженості» називає «тимосом» (від грец. thymos), що являє собою осередок людських суджень про гідність та визнання у різний спосіб: «...якщо людина отримує цю позитивну оцінку, то відчуває гордість, якщо ж ні - то гнів (коли вважає, що ії недооцінюють), або сором (коли розуміє, що не відповідає стандартам інших людей)» [9, с. 30].

Можна стверджувати, що за наявності надзвичайно насиченого потоку найрізноманітнішої розрізненої інформації, зовнішність в сучасному інформаційному просторі постає простим комунікативним орієнтиром, показником того, що для людини є добре, а що погане. Тобто без надмірних зусиль, екзистенціального пошуку можна водночас стати популярним, успішним, затребуваним та гідним.

Цікавою $є$ думка сучасної дослідниці феномена краси Науомі Вульф. У своїй книзі «Міф про красу: Стереотипи проти жінки» вона зазначає, що в сьогоденні «краса стає валютою на кшталт золотому стандарту», а образи, які ми бачимо довкола, базуються лише 
на вигаданих міфах. На думку Н. Вульф краса так само ілюзорна як і історія про Афродіту, судження Париса та яблуко розбрату: «це лише зручна вигадка, якою користуються багатомільярдні індустрії... що створюють образи та продають їх жінкам наче опіум... викликаючи заздрість та жагу» [13, с. 92]. Дозволимо собі в повній мірі не погодитись 3 думкою дослідниці, та підкреслимо, що іноді штучно створений образ людини буває настільки привабливим, естетично-виразним та гарним усією своєю візуальною наповненістю, що претендує на роль культурного шедевра. Але звичайно така штучна краса не може в повній мірі замінити істину природню красу, оскільки «фетишизація викорінює 3 мистецтва його парадоксальність, у результаті чого й мистецтво перестає бути самоочевидним... воно вже позбавлене впевненості в тому, що витвір створюється заради нього самого» $[13$, c. 36]. Так, наприклад, оголене тіло тяжко перетворити на мистецтво безпосереднім відтворенням, «оголені фігури не викликають у нас емпатію, натомість лише розчаровують та зневіряють...» [10, с. 126].

Говорячи про тілесну красу, цікавою $є$ концепція «трьох тіл» Поля Валері, який вважав, що першим тілом людини $\epsilon$ те, яким вона «володіє», в якому живе. Це те «Я», яке людина відчуває, стаючи найважливішим об'єктом у світі. Другим її тілом є публічний фасад, тобто тіло, яке необхідно постійно створювати ... «тіло, на якому бачимо шати, орнаменти, захист, яке бачить або бажає бачити кохання $\mathrm{i}$ якого хочеться торкатися». Третім тілом людини є фізична машина, про яку людина знає дуже мало та «не має жодних підстав навіть підозрювати про печінку, мозок чи нирки» [12, с. 17]. Це те тіло, від якого людина найбільше віддалена та яке прикриває краса. Істина задача людини об'єднати ці три тіла в одне, стати не лише продуктом природи, а гармонійно поєднати внутрішнє і зовнішнє, духовне й душевне. Саме тому, краса, як «чиста краса», що представляється в сукупності неідеальних критеріїв, хаотичних 3 математичного погляду, має справу з біологією, а не з ідеальними числами чи пропорціями. При цьому соціальні ефекти від сексуальних домагань вродливих та дискримінації невродливих до нехтування не такої помітної «внутрішньої краси», аж ніяк не можна вважати найважливішими.

Краса людини публічної в сьогоденні не повинна стати лише бажанням та боротьбою за будь яких умов бути реалізованою поза власним тілом. Людині в сьогоденному інформаційному просторі не потрібно бути лише затребуваним красивим об'єктом, що не здатен розкрити свою духовність через надмірне прискорене бажання легкого успіху. По-суті, «щоб жити у світі, людина повинна, перш за все, бути втіленою у цей світ, займати у ньому певний простір, бути зримою, 126 
тілесною» $[1$, с. 20$]$, але така диференціація не має обмежуватись лише «зовнішнім», оскільки одне існує через інше. Втрата канонічних рис зовнішньої виразності може підкреслювати власну самість, ідентичність, та внутрішнє «Я» людини, розкриваючи ii iстину гармонійну красу.

\section{Література:}

1. Адорно В. Теорія естетики / пер. 3 нім. П. Таращук. Київ: Видавництво Соломія Павлично «Основи», 2002. 522 с.

2. Васильєва Л. А. Людина публічна в культур-комунікативному просторі сучасності. Харків : Мачулін, 2019. 392 с.

3. Васильєва Л. А. Публічна ідентифікація сучасної людини. Проблеми саморозвитку особистості в сучасному суспільстві : 2021 рік : матеріали II Міжнар. наук.-практ. конф., 26-27 бер. 2021 р. Харків: НЮУ ім. Ярослава Мудрого. Харків : Друкарня Мадрид. 2021. С. 139-141.

4. Газнюк Л. Філософські етюди екзистенціально-соматичного буття : монографія. Київ : Парапан, 2008. 368 с.

5. История Красоты / пер. А. Сабашниковой. Москва : Слово, 2006. $440 \mathrm{c}$.

6. Крилова С. А. Краса людини в життєвих практиках культури. Досвід соціальної та культурної метаантропології і андрогін-аналізу : монографія. Київ : КНТ, 2019. 563 с.

7. Сеннет Р. Падение публичного человека / пер. с англ. О. Исаева и др. Москва : Логос. 2002. 424 с.

8. Татаркевич В. Історія шести понять. Мистецтво. Прекрасне. Форма. Творчість. Відтворництво. Естетичне переживання / пер. В. Корниенка, 2001. Київ : Юніверс. 368 с.

9. Фукуяма Ф. Ідентичність. Потреба в гідності й політика скривдженності / пер. 3 англ. Тетяна Сахно. Київ : Наш формат. 2020. $192 \mathrm{c}$.

10. Etcoff N. Survival of the Prettiest. The Science of Beauty. Anchor Book. Random House, Inc. New York, 1999. 368 p.

11. Heemsbergen L., Bowtell G., Vincent J. Conceptualising Augmented Reality: From virtual divides to mediated dynamics. Sage Journals. 2021. http://doi.org/10.1177/1354856521989514

12. Valery P. «Some simple reflection on the body» in Fragments for A. History of the Human Body / ed. Michel Feher. Part 2. New York : Zone, 1989. $264 \mathrm{p}$.

13. Wolf N. The Beauty Myth : How Images of Beauty Are Used Against Women. New York: Anchor, 1992. 312 p. 